Wojciech Kocot*

\title{
An Analysis of the Causes of Damage to Reinforced Concrete Road Viaduct Located in the Mining Area**
}

\section{Introduction}

The subject of the research was a road viaduct (Fig. 1), located within a provincial road over two railway tracks, in the mining area. As a result of the conducted inspection, numerous damages to the object were identified. Due to the location of the viaduct it was suspected that the damages resulted from impacts associated with mining exploitation. The article contains an analysis of the causes of damage to the viaduct, based on the current state of knowledge (e.g. [3-6]).

\section{Construction and Technical Condition of the Structure}

The subject viaduct has a statically indeterminate reinforced concrete monolithic supporting structure in the form of a three-span frame, with span lengths of $13.75 \mathrm{~m}+18.55 \mathrm{~m}+13.40 \mathrm{~m}$ (Figs 1, 2).

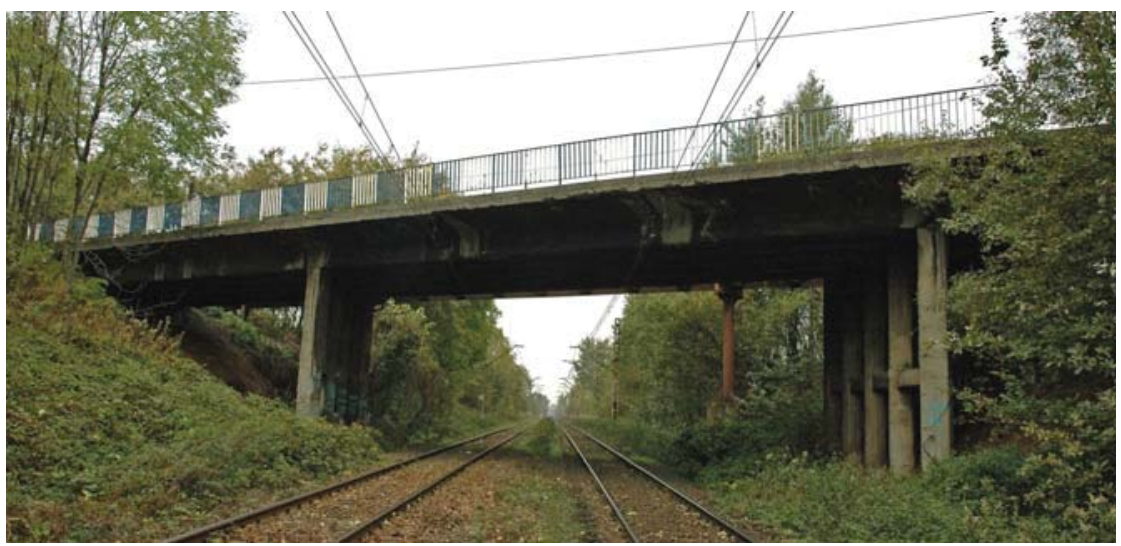

Fig. 1. South side view of the viaduct

\footnotetext{
* AGH University of Science and Technology, Faculty of Mining Surveying and Environmental Engineering, Department of Engineering Surveying and Civil Engineering, Krakow, Poland

** The paper was prepared within the scope of the AGH statutory research no. 11.11.150.005
} 


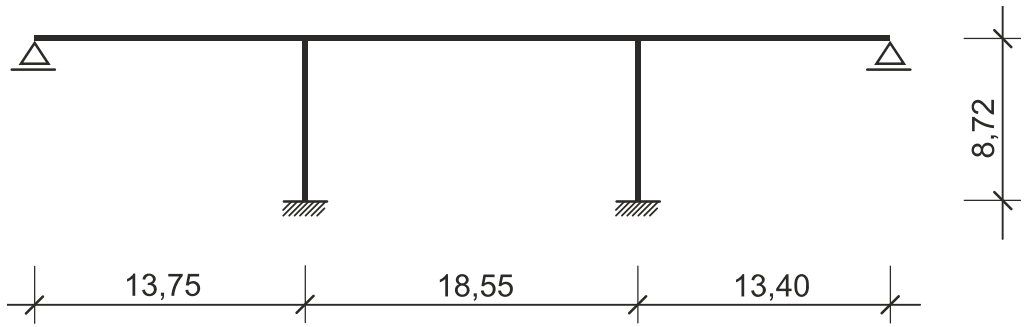

Fig. 2. Static diagram of the viaduct

Frame bolt (viaduct span) is made up by a beam-and-slab system built of five oblong beams joined together by means of a bridge deck and crossbars (Fig. 3). Pavement cantilevers with the reach of about $1.8 \mathrm{~m}$ were made on both sides of the span. The total span width is less than $10 \mathrm{~m}$, of which $6.9 \mathrm{~m}$ constitutes the road. The total length of the span measured parallelly to the road equals 46.35 meters.

Each of the piers is made up of five pillars with square cross-section $(55 \times 55 \mathrm{~cm})-$ one for each beam of the span. All pillars of the pier are founded on the common foundation beam and connected in the middle with a reinforced concrete crossbar (Fig. 3). The pillars are connected in a rigid manner with the load-bearing beams of the span.

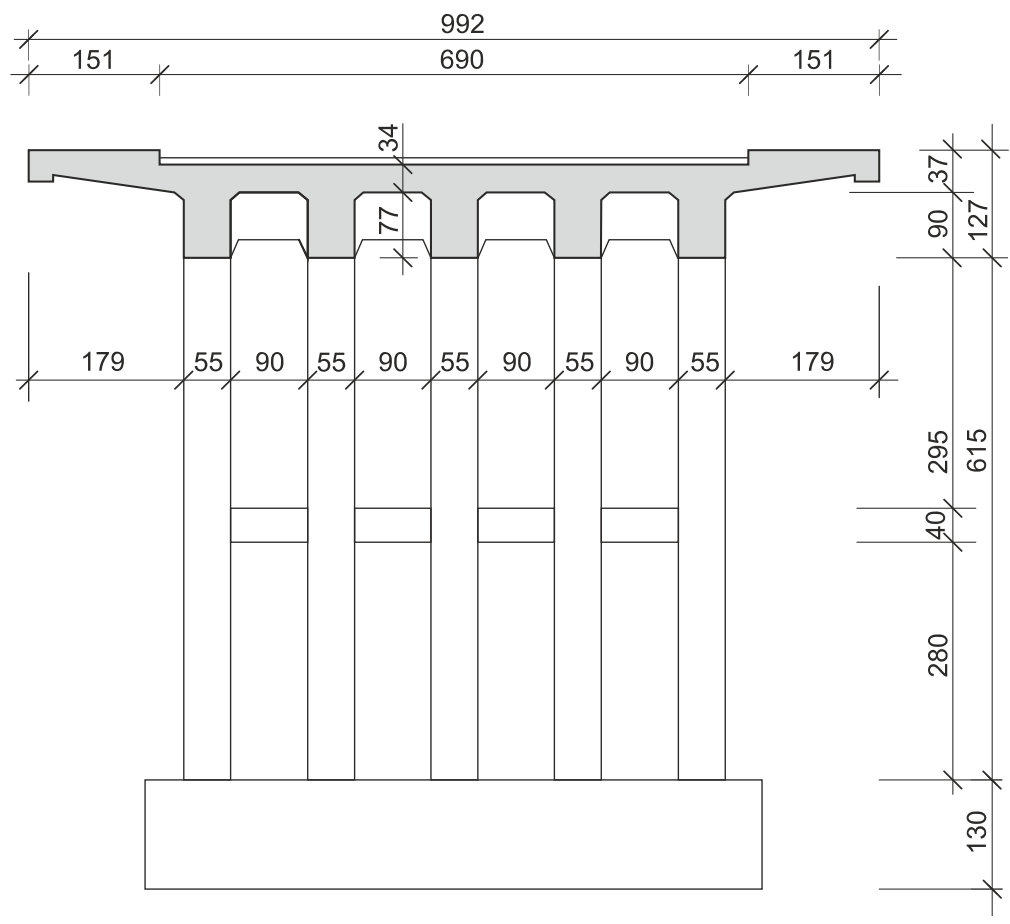

Fig. 3. Viaduct span cross-section and view of the pier 
Both abutments were made as monolithic and solid, with the wing walls parallel to the axis of the road. A back wall shaped at the abutments served as a basis for transition slabs. The viaduct has no bearings. The span beams were based on the abutments by means of a tar board belt. The object was erected in 1952, that is, when mining activities were not planned in this area. Therefore, when designing the structure, preventive measures against the impacts of mining were not taken into account.

The conducted on-site inspection revealed the existence of numerous damages and inaccuracies. In the case of the spans, the most significant damages are concentrated around the cornice, pavement cantilever and the outermost supporting beam on both sides of the span. They are all due to the more or less advanced corrosion of concrete, and sometimes even the corrosion of reinforcing steel. The corrosion of reinforced concrete elements of the span is associated with the long-term effects of dampness and it is found mainly in the vicinity of the leaks on the technological joints of the pavement cantilever. Corrosion usually covers the outer surface and the underside of the outermost beam. Flaking and loss of reinforcement coating frequently occur in corroded places. Coating cracks running on the main beams along the main reinforcement suggest that underneath rods corrode locally. Binding minerals washed out of the concrete by water are deposited, locally forming stalactites. The greatest extent of damage was identified on the south side of the viaduct, directly above the eastern track.

No significant damage to the inner surfaces of the outermost beams or other structural elements of the span (internal load-bearing beams, the underside of the bridge deck and the crossbars) were identified. The only abnormalities noticed there are a few micro scratches visible on the surface of the concrete.

The most significant damage to the piers includes the flaking of concrete coating and the corrosion of reinforcement. They generally occur in the corners of the pillars, mostly in the lower parts (e.g. Fig. 4). The corrosion of concrete is also visible directly at the ground level. The corrosion of the exposed reinforcement is sometimes very advanced. In the upper parts of the pillars there are only a few losses of the coating. However, it is often cracked or scratched, which proves the corrosion of the coated reinforcement. The described damage relates to the outermost beams in the greatest extent.

Damages to abutments include cracks in the back walls. The largest, with the aperture of about $100 \mathrm{~mm}$ were noticed in the north-west corner (Fig. 5). It is accompanied by a clear dislocation of the wing wall towards the outside. A crack of a smaller aperture, but with chipping and corrosion of concrete occurs at the same abutment on the south side (Fig. 6). A crack on the north side of the eastern abutment has a very similar course and aperture. The smallest one, with the aperture of about $1 \mathrm{~mm}$ occurs in the south-east corner. It should be noted that the cracked parts of the abutments were not reinforced.

Transverse expansion joints between the load-bearing system of the span and the back wall of the abutments are tight in the places where they are visible (that is, on the outermost beams). 


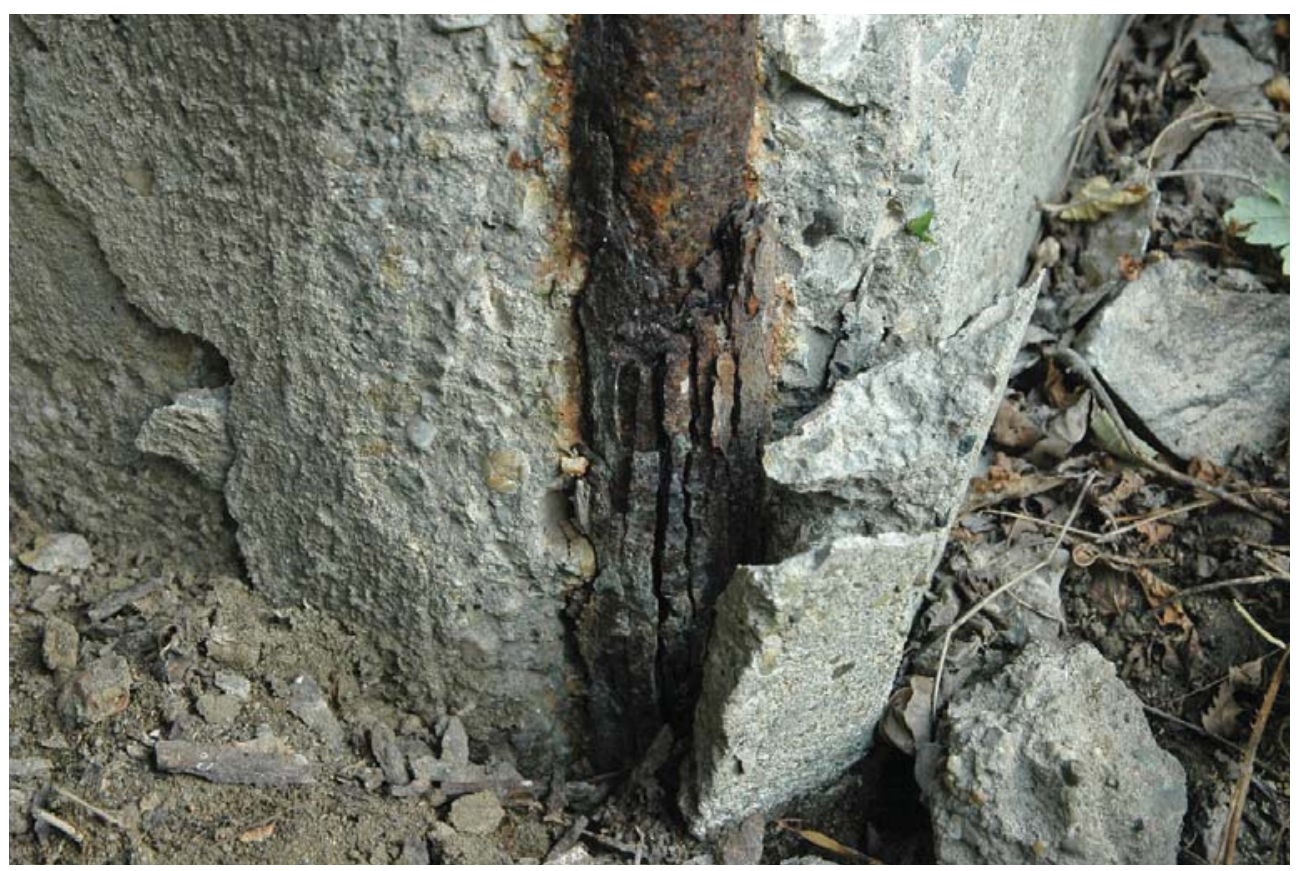

Fig. 4. South pillar of the eastern pier - visible losses of concrete coating and advanced reinforcement corrosion

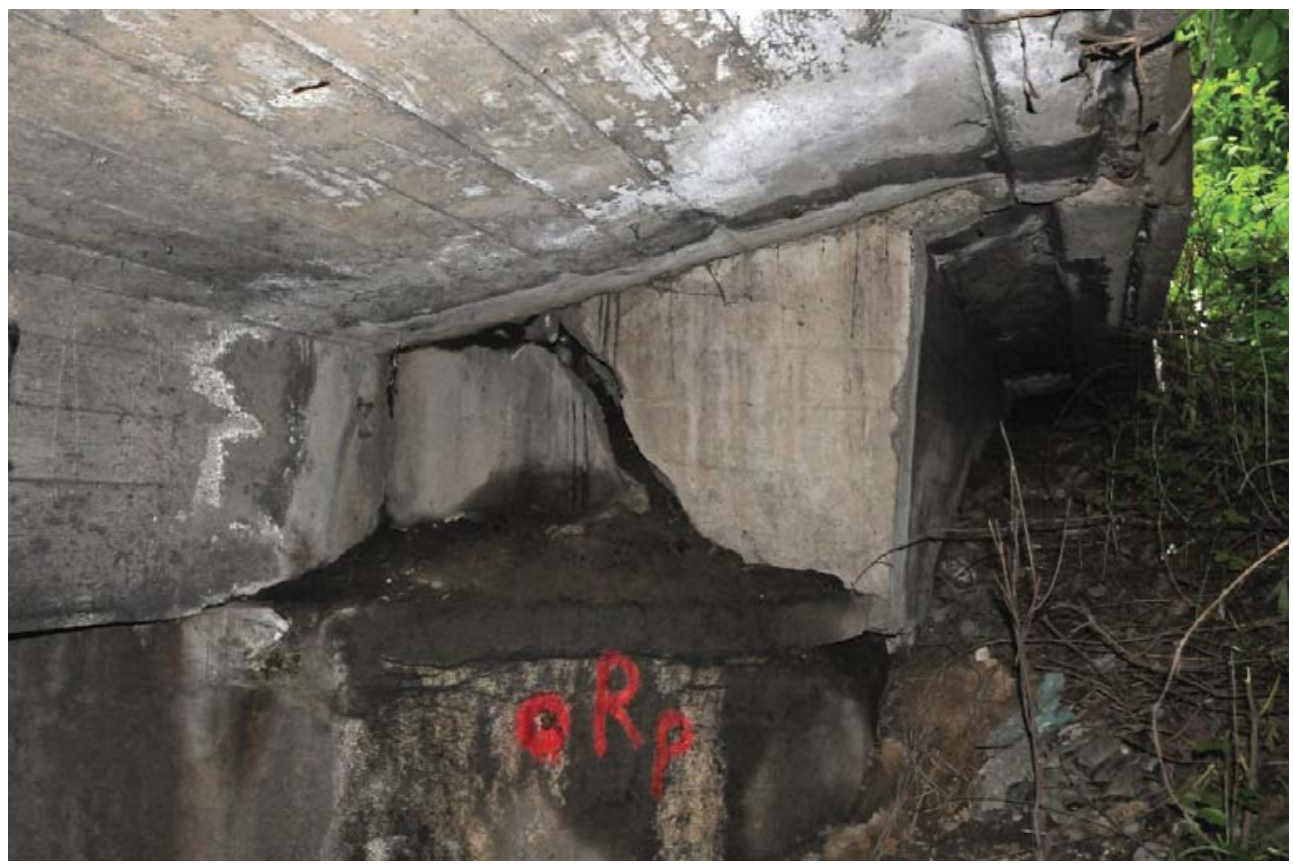

Fig. 5. Western abutment, north side - visible crack of the back wall and dislocation of broken off parts towards the outside 


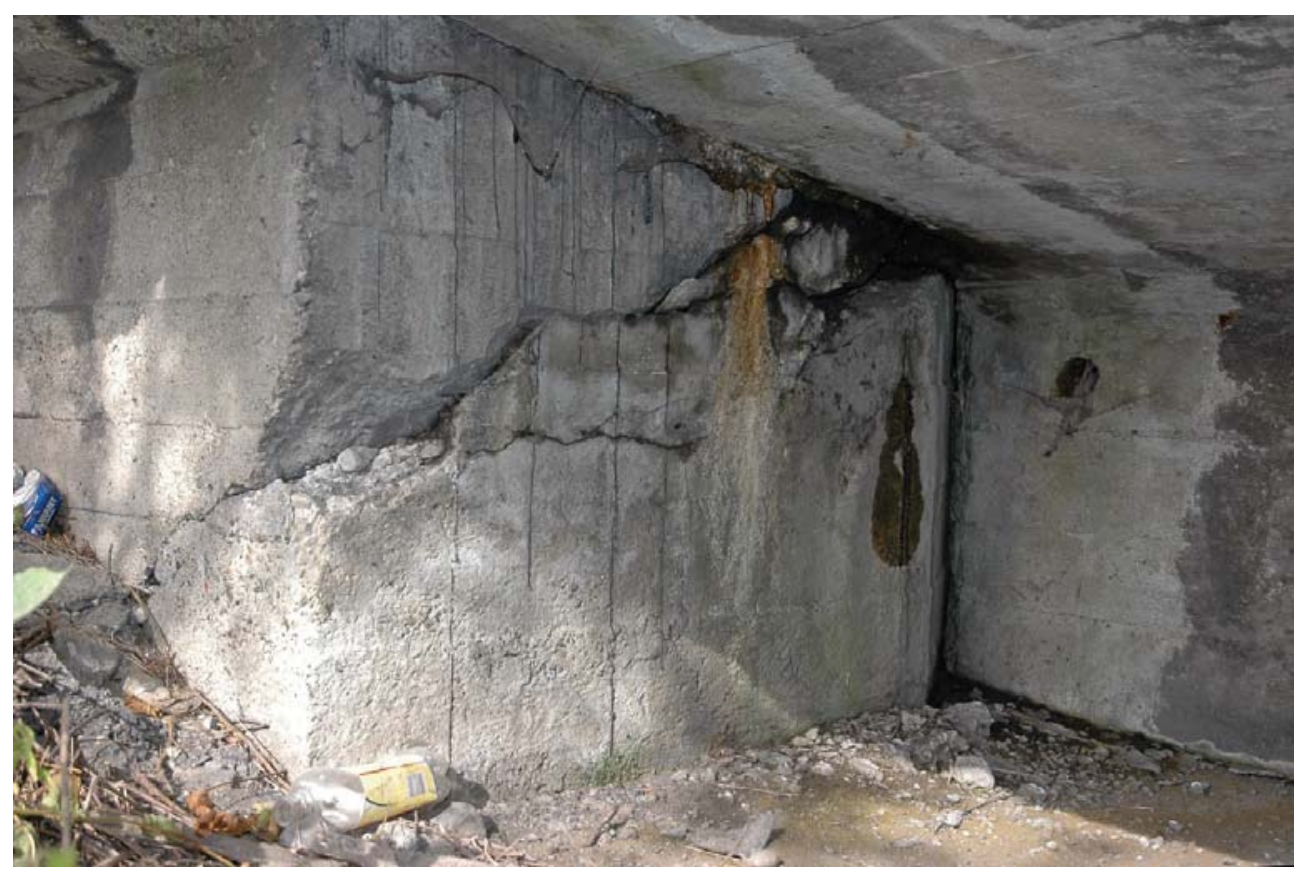

Fig. 6. Western abutment, south side - visible crack of the back wall and chipping of concrete

\section{Mining Exploitation Conducted in the Area of the Viaduct}

Table 1 has been prepared based on information acquired from the Mining Plant. It summarizes data on the exploitation of the walls in the vicinity of the viaduct, as well as the associated impacts of mining. Given in each column land deformation indices are to be understood as predicted.

The data presented in table 1 leads to a conclusion that most exploited walls, due to a significant distance from the viaduct, did not have any virtual effect upon it. The walls, whose impact on the structure could be significant, have been highlighted in bold. The first one is the wall P-1 in the seam 346/1, which completed its course in 1981, at a distance of approximately $200 \mathrm{~m}$ southeast of the center of the viaduct. Another one, (exploited after several years), wall P-8 in the seam 357/1 completed its course in 2009, at approximately $80 \mathrm{~m}$ east of the center of the viaduct. At the location of the structure, both of these walls resulted in the formation of horizontal tensile strains and a convex curvature in a direction parallel to the axis of the structure. In both cases the effects were small, with indices much below the $1^{\text {st }}$ category of a mining area. The presented data show that by 2011 at the location of the viaduct there were no horizontal compressive strains. 
Table 1. Exploited walls in the vicinity of the viaduct and the associated predicted indices of area deformation

\begin{tabular}{|c|c|c|c|c|c|c|c|c|c|}
\hline \multirow{3}{*}{$\begin{array}{c}\text { Year of } \\
\text { exploitation }\end{array}$} & \multirow{3}{*}{ Seam } & \multirow{3}{*}{ Wall } & \multirow{3}{*}{$\begin{array}{c}\text { Distance } \\
\text { from the } \\
\text { viaduct } \\
{[\mathrm{m}]}\end{array}$} & \multirow{3}{*}{ Towards } & \multicolumn{5}{|c|}{ Indices in main directions } \\
\hline & & & & & \multicolumn{2}{|c|}{ extreme } & \multicolumn{3}{|c|}{ final } \\
\hline & & & & & $\begin{array}{c}\varepsilon \\
{[\mathrm{mm} / \mathrm{m}]}\end{array}$ & $\begin{array}{c}R \\
{[\mathrm{~km}]}\end{array}$ & $\begin{array}{c}\varepsilon \\
{[\mathrm{mm} / \mathrm{m}]}\end{array}$ & $\begin{array}{c}R \\
{[\mathrm{~km}]}\end{array}$ & $\begin{array}{c}w \\
{[\mathrm{~mm}]}\end{array}$ \\
\hline 1980-1981 & $346 / 1$ & P-1 & 194 & NE & +0.6 & 155 & +0.6 & 155 & 21 \\
\hline 1988-1989 & $355 / 1$ & P-3 & 474 & $\mathrm{~W}$ & 0.0 & $>1000$ & 0.0 & $>1000$ & 1 \\
\hline 1991-1992 & $356 / 1$ & P-6 & 517 & W & 0.0 & $>1000$ & 0.0 & $>1000$ & 0 \\
\hline 1993-1994 & $357 / 1$ & P-6 & 471 & W & +0.1 & $>1000$ & +0.1 & $>1000$ & 2 \\
\hline 2007 & $357 / 1$ & W-10 & 479 & $\mathrm{~N}$ & +0.1 & $>1000$ & +0.1 & $>1000$ & 2 \\
\hline 2008-2009 & $357 / 1$ & $\mathrm{~W}-8$ & 534 & NE & 0.0 & $>1000$ & 0.0 & $>1000$ & 0 \\
\hline 2008-2009 & $357 / 1$ & P-8 & 83 & $\mathrm{E}$ & +1.0 & 126 & +0.9 & 139 & 213 \\
\hline 2009-2010 & $360 / 1$ & W-6 & 547 & NE & 0.0 & $>1000$ & 0.0 & $>1000$ & 1 \\
\hline 2010-2011 & $360 / 1$ & $\mathrm{~W}-7$ & 503 & $\mathrm{~N}$ & +0.1 & $>1000$ & +0.1 & $>1000$ & 3 \\
\hline 2009-2011 & 361 & $\mathrm{~W}-3$ & 581 & NW & 0.0 & $>1000$ & 0.0 & $>1000$ & 0 \\
\hline
\end{tabular}

\section{Analysis of Geodetic Observations of the Viaduct}

The only observations conducted so far included leveling of an elevation benchmark fixed on the viaduct. From the data provided by the Mining Plant it is evident that since 1973 the total subsidence of the viaduct has reached $462 \mathrm{~mm}$.

In 2011 surveys were carried out, which aimed at the detection of possible strains of structural elements (span and piers). These types of surveys were carried out for the first time, therefore there is a lack of comparative data in this respect. In particular, there is the lack of information regarding executive deviations, which with the technology used (structural elements wet cast in careless formwork) could turn out to be quite significant.

The measurement of span deflection was carried out by observing the underside of both outermost beams near their outer edge. The leveled points were: the underside of the beam of the middle span in the half of its length, and the undersides of the beams of the side spans near the piers and abutments (the total of five points). Deviations from the theoretical line were surveyed, relevant to the diagram presented in figure 2. The survey results have been presented in figure 7 (outermost north beam), and figure 8 (outermost south beam). In both cases it is the view from the south side, thus the western span is on the left side, and the eastern on the right. 


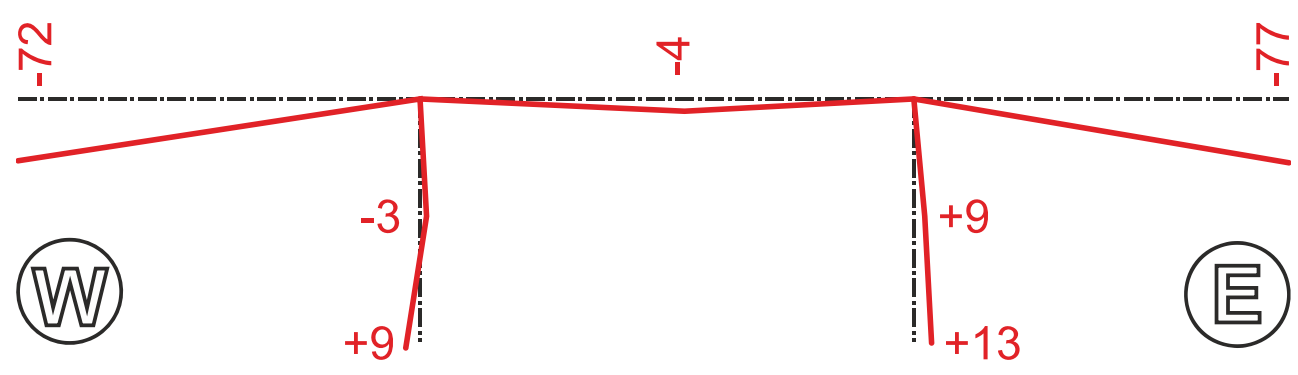

Rys. 7. Deviations from the theoretical axis of the viaduct elements on the north side [mm]

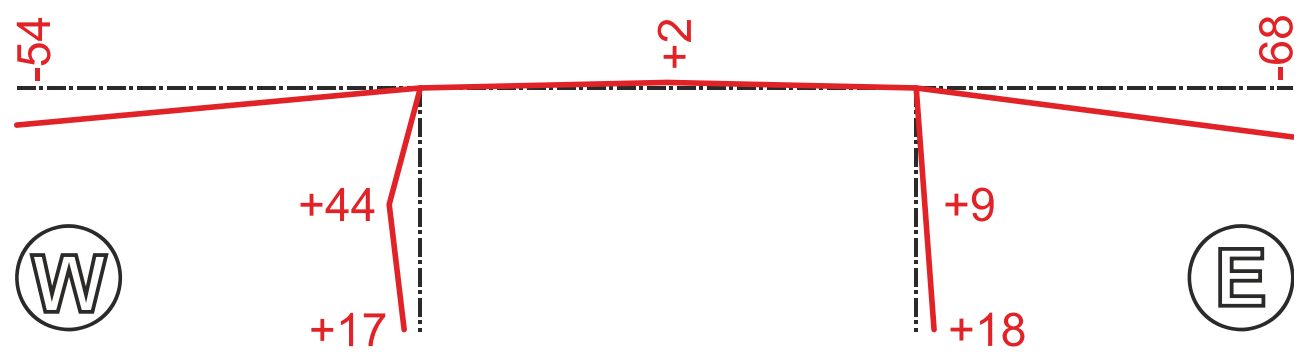

Rys. 8. Deviations from the theoretical axis of the viaduct elements on the south side [mm]

The measurement indicates a several-centimeter subsidence of the span endpoints (on the abutments) compared with the points on the piers (values from $-54 \mathrm{~mm}$ to $-77 \mathrm{~mm}$ ). This result can be interpreted as a shape attributed to the span at the implementation stage, which often occurs when a vertical alignment of the road on the object is in a convex vertical curve. The deviations observed in the middle of the main span on the south side equals to $2 \mathrm{~mm}$ and on the north side $-4 \mathrm{~mm}$. Taking into account surface irregularities associated with the corrosion damage of the observed outermost beams, it can be claimed that the main span in the vertical section is a straight line.

Measurement of the piers verticality was based on the observations of four outermost pillars. For each of the observed pillars, the position of the middle of the sections in their upper and lower parts were determined. Since each of the piers is covered with soil in its lower part, the lower section was measured at the level enabling observations, and the upper section at the connection of the pillar with the span beam. The sign " + " indicated deviations in the direction of the foundations moving away from each other, and the sign "-" indicated approaching. The survey results show a slight dislocation of the foundation beams away from each other (Figs 7,8). These dislocations, measured just above the surface of the ground, perpendicular to the railroad tracks, range from $9 \mathrm{~mm}$ to $17 \mathrm{~mm}$ for the western support and from $13 \mathrm{~mm}$ to $18 \mathrm{~mm}$ for the eastern one. 
While checking verticality, an additional measurement of straightness (deflection) of the outermost pillars of the piers was carried out. For this purpose, a similar survey to that in the lower and upper parts of the pillars was also conducted in the middle part. In the case of the eastern pier, it turned out that the south pillar is not deflected, and the north pillar has a convex curvature of the deflection value $2 \mathrm{~mm}$. In the case of the western pier, on the south side there was a convex curvature of the deflection value $35 \mathrm{~mm}$, and on the north - a concave curvature of the deflection value $7 \mathrm{~mm}$. Thus it follows that the pillars of the western pier are deflected in opposite directions. In addition, the way they are deflected is in conflict with the measured deflection of the pillars. In this situation, the obtained results should be considered unreliable and resulting from performance inaccuracy, which, in the case of the pillars, is even greater than in the case of the span.

To conclude, it should be stated that all the measured displacements of the viaduct are small. In the context of the current technical condition of the structure and not very high quality of executive works, they may be, in fact, the result of performance inaccuracy. The largest of the measured displacements is the increase in the distance between the piers at the bottom of a total of about $30 \mathrm{~mm}$, which is consistent with the data presented in table 1.

\section{Impact Assessment of Mining Exploitation on the Technical Condition of the Viaduct}

A vast majority of damage to the spans and piers structure is typical corrosion damage related to long-term effects of dampness, whose presence is associated with improper drainage of rain water. A few minor scratches on the underside of the deck and the inner beams are to be explained by shrinkage of concrete. In this situation, the only damage the appearance of which should be analyzed in terms of a possible association with the mining exploitation is the cracking of the abutment back walls.

These cracks occur in varying degrees in all four corners of the viaduct (c.f. Section 2). Yielding to the first impression, it seems that the cause of the cracking is the pressure of the abutments (wing walls and back wall) on the span resulting from creeping. However, the conducted analysis of mining data and the relative position of the object and the exploited walls show clearly that in the location of the viaduct there were only weak horizontal tensile strains. The course of the largest crack (in the north-west corner - Fig. 5) and the direction of dislocation of the broken off wing wall indicate that the force which did it, was not directed parallelly to the axis of the viaduct, but it was perpendicular to it. This could be, for example, pressure on both wing walls of the soil located between them, loaded with traffic. The support of such a thesis is the fact that the largest dislocation of the broken off wing wall occurred in the north-west corner, which is where the ground level on the other (outer) side of the wing wall is the lowest, and due to this fact it does not balance the pressure of the soil formed between the wing walls. Much smaller dislocations 
occurred in the south-west corner (Fig. 6) and north-east corner, where the ground level on the other side of the wing wall is much higher. The smallest crack without dislocation occurred in the south-east corner. This wing wall is almost completely buried, thanks to which the pressure of the soil inside and outside of the wing wall balance. It should be emphasized that the damaged elements were made as concrete and they do not have any reinforcement (Fig. 5).

To conclude, it should be noted that there is no evidence to confirm the causal relationship between the occurrence of the damages and the activity of the mining plant.

\section{Summary}

This article presents an example of damages which could be misinterpreted as mining damages. Thanks to the conducted analysis it was shown, however, that mining exploitation could not cause the described damages. At the same time other, non-mining causes of damage, were pointed out. This and many similar cases (e.g. [1, 2]) suggest that in order to determine the real causes of damage to building structures, it is necessary to carry out an analysis taking into account both the general mining and construction factors, as well as exploitation conditions of the object itself.

\section{References}

[1] Barycz S., Wodyński A.: Błędy związane z posadowieniem budynków jako przyczyna szkód pseudogórniczych (Errors related to construction of buildings as a cause of pseudo mining damage). Przegląd Górniczy, nr 3, 1994, pp. 28-32.

[2] Kocot W., Piwowarski W.: Przykład niewłaściwej oceny przyczyn powstania uszkodzeń budynku na terenach górniczych (An example of incorrect assessement of a building damage in mining area). XI Dni Miernictwa Górniczego i Ochrony Terenów Górniczych, Kraków 28-29.05.2009, Uczelniane Wydawnictwa Naukowo-Dydaktyczne AGH, Kraków 2009.

[3] Kwiatek J.: Obiekty budowlane na terenach górniczych (Building structures in mining areas) (wyd. 2 zmienione i rozszerzone). Wydawnictwo GIG, Katowice 2007.

[4] Kwiatek J. (red.): Ochrona obiektów budowlanych na terenach górniczych (Protection of building structures in mining areas). Wydawnictwo GIG, Katowice 1997.

[5] Rosikoń A.: Budownictwo komunikacyjne na terenach objętych szkodami górniczymi (Construction of communication in the areas of mining damage). Wydawnictwa Komunikacji i Łączności, Warszawa 1979.

[6] Wymagania techniczne dla obiektów budowlanych wznoszonych na terenach górniczych (Technical requirements for building structures erected in mining areas). Wydawnictwo ITB, Warszawa 2007. 